\title{
DIMENSI INOVASI SOSIAL PADA SISTEM PERTANIAN PERTAKULTUR PROGRAM PETANI MAJU 4.0 PERTAMINA HULU MAHAKAM LAPANGAN BSP
}

\author{
Lalu Muhammad Azwar', Ranu Wijaya2 ${ }^{2}$, Kris Radityorini ${ }^{3}$ \\ ${ }^{1}$ CDO Pertamina Hulu Mahakam Lapangan BSP \\ ${ }^{2}$ Head Service HDI Departemen CSR Pertamina Hulu Mahakam \\ ${ }^{3}$ CSR Officer Pertamina Hulu Mahakam Lapangan BSP \\ Email : lalu-muhammad.azwar@phm.mitrakerja.pertamina.com
}

\begin{abstract}
This article aims to provide an overview of the dimensions of social innovation carried out in the Pertamina Hulu Mahakam BSP CSR program. The green revolution policy in agriculture in the 1970s had an impact on the decreasing productivity of agricultural land. The next problem is a decrease in the age regeneration rate of farmers. Meanwhile, the unemployment rate of the workforce during the pandemic is increasing. Pertamina Hulu Mahakam BSP as one of the stakeholders promotes a CSR program in the agricultural sector entitled 'Petani Maju 4.0'. The Program 'Petani Maju 4.0' has a mission to build farmer capacity with the concept of environmentally friendly agriculture and farmer regeneration. The mission for the concept of environmentally friendly agriculture is carried out with the Pertaculture system which is managed by millennial youth in the Ring 1 area of Pertamina Hulu Mahakam BSP. The qualitative approach used is descriptive qualitative. The descriptive analysis approach was chosen because the author will tell the process of social innovation in the development of the Pertaculture agricultural system. Data collection was carried out by observation, interviews, and focus group discussions with various stakeholders. The results of the analysis show that the social innovation dimension of the Pertaculture agricultural system lies in the element of novelty, being able to answer problems, making humans the main subject of institutionalized program recipients in agricultural groups.
\end{abstract}

Keywords: Social Innovation, Pertaculture, Petani Maju 4.0, CSR

\begin{abstract}
Abstrak
Artikel ini bertujuan untuk memberikan gambaran mengenai dimensi inovasi sosial yang dilakukan pada program CSR Pertamina Hulu Mahakam Lapangan BSP. Kebijakan revolusi hijau di bidang pertanian pada dekade tahun 1970an berdampak pada menurunnya produktifitas tanah pertanian. Permasalahan selanjutnya terjadi penurunan tingkat regenarasi usia petani. Sementara angka pengangguran usia angkatan kerja ditengah masa pandemi semakin bertambah. Pemerintah dan stakeholder terkait berupaya untuk melakukan perbaikan dengan menggalakkan pertanian yang ramah lingkungan dan mengampanyekan pemuda untuk kembali bertani. Pertamina Hulu Mahakam BSP sebagai salah satu stakeholder menggalakan program CSR di bidang pertanian bertajuk Petani Maju 4.0. Program Petani Maju 4.0 memiliki misi untuk membangun kapasitas petani dengan konsep pertanian ramah lingkungan dan regenerasi petani. Misi untuk konsep pertanian ramah lingkungan dilaksanakan dengan sistem Pertakultur yang dikelola oleh para pemuda milenial di wilayah Ring 1 Pertamina Hulu Mahakam BSP. Proses pengumpulan data dan penyusunan dilakukan dengan metode kualitatif. Pendekatan kualitatif yang digunakan adalah kualitatif deskriftif. Pendekatan analisis deskriptif dipilih karena penulis akan menceritakan proses inovasi sosial dalam pengembangan sistem pertanian Pertakultur. Pengumpulan data dilakukan dengan observasi, wawancara, dan focus grup discussion dengan berbagai stakeholder. Analisa teoritik dilakukan dengan konsep inovasi sosial. Inovasi sosial adalah sebuah upaya untuk melakukan perubahan sistemik di masyarakat. Pendekatan yang dilakukan untuk melakukan perubahan sosial ini berupa institusionalisasi, pengembangan kapasitas masyarakat dan menciptakan sistem baru yang lebih efektif dibandingkan dengan sistem yang berlaku sebelumnya. Hasil dari analisa menunjukkan bahwa dimensi inovasi sosial sistem pertanian Pertakultur terletak pada unsur kebaruan, mampu untuk menjawab permasalahan, menjadikan manusia sebagai subjek utama penerima program terinstitusionalisasi dalam kelompok-kelompok pertanian.
\end{abstract}

Kata Kunci : Inovasi Sosial, Pertakultur, Petani Maju 4.0, CSR. 
Learning Society: Jurnal CSR, Pendidikan dan Pemberdayaan Masyarakat

Jurnal Program Studi Pendidikan Masyarakat

Universitas Mulawarman

Vol. 2 No. 1, Juni 2021. Hal: 9-13

\section{Pendahuluan}

Sektor pertanian di Indonesia menghadapi berbagai tantangan dan permasalahan. Pertumbuhan penduduk yang meningkat mengakibatkan terjadinya konversi lahan pertanian menjadi pemukiman, infrastruktur publik dan industri nonpertanian. Badan Pusat Statistik (BPS) mencatat terjadi penurunan jumlah lahan pertanian dari 7,75 juta $\mathrm{Ha}$ di tahun 2017 menjadi 7,1 juta $\mathrm{Ha}$ pada tahun 2018.1 Menurut Mulyani (2016:125), laju konversi lahan pertanian secara merata terjadi di seluruh wilayah Indonesia, termasuk Kalimantan. Kasus yang terjadi di Kalimantan adalah konversi lahan sawah produktif menjadi lahan sawit. Fenomena ini terjadi karena perkembangan industri kelapa sawit di Pulau Kalimantan kian meningkat dari tahun 2000 sampai tahun 2014 (Mulyani, 2016:126).

Selain konversi lahan pertanian, permasalahan sektor pertanian adalah produktifitas tanah yang kian menurun. Lahan pertanian yang semakin berkurang disertai dengan menurunnya produktifitas lahan menjadi ancaman yang serius terhadap pemenuhan kebutuhan pangan. Faktor yang menyebabkan menurunnya produktifitas tanah ini adalah dampak dari kebijakan revolusi hijau. Sistem pertanian ramah lingkungan berbasis kearifan lokal yang dimiliki oleh petani Indonesia diubah dengan penggunaan pupuk kimia untuk mengejar peningkatan produksi di tahun 1970-an. Kebijakan revolusi hijau adalah upaya modernisasi sektor pertanian yang mengubah cara produksi tradisional tanpa mempertimbangkan dampak modernisasi terhadap keberlanjutan lingkungan (Prayogo, et al, 2019:98). Dampak kebijakan tersebut dirasakan saat ini dengan ketergantungan petani terhadap produk-produk pupuk kimia untuk mengolah lahan. Penggunaan pupuk kimia menjadi salah satu pengeluaran terbesar petani dalam melakukan produksi.

Permasalahan turunan dari masalah konversi lahan dan menurunnya produktifitas tanah adalah regenerasi petani. Menurut data BPS Agustus 2019, penduduk yang bekerja di sektor pertanian berjumlah 34,58 juta orang, turun 1,12 juta orang dibandingkan tahun 2018.2 Tiga masalah yang terjadi ini mengakibatkan minimnya tingkat kedaulatan pangan dari hasil pertanian. Thomas Malthus seorang ahli demografi di pertengahan abad 19 menyatakan bahwa manusia akan mengalami krisis pangan dalam jangka panjang karena pertumbuhan penduduk berkembang pesat dengan deret ukur, sementara pertumbuhan deret pangan berkembang dengan deret hitung.

Pemerintah dan berbagai stakeholder tentunya melakukan langkah antisipatif untuk mencegah krisis pangan yang dikemukakan oleh Malthus. Pertamina Hulu Mahakam (PHM) Lapangan BSP salah satu stakeholder yang memiliki kepedulian terhadap permasalahan di sektor pertanian. Melalui program CSR Petani Maju 4.0, PHM Lapangan BSP berupaya untuk membantu pemerintah menghadapi masalah pertanian di Kecamatan Samboja. Lima Kelurahan di wilayah administratif Kecamatan Samboja, Kabupaten 
Learning Society: Jurnal CSR, Pendidikan dan Pemberdayaan Masyarakat

Jurnal Program Studi Pendidikan Masyarakat

Universitas Mulawarman

Vol. 2 No. 1, Juni 2021. Hal: 9-13

Kutai Kertanegara menjadi wilayah Ring 1 PHM Lapangan BSP.

Program CSR Petani Maju 4.0 PHM Lapangan BSP muncul dari identifikasi permasalahan sosial dalam social mapping yang dilakukan pada tahun 2018. Terdapat masalah pengangguran yang terjadi karena pengurangan pekerjaan di sektor industri ekstraktif. Berdasarkan penelitian yang sama di wilayah Ring 1 PHM Lapangan BSP, terdapat potensi besar di sektor pertanian yang bisa menjadi alternatif untuk mengurangi jumlah pengangguran. Potensi tersebut berupa lahan tidur yang belum termanfaatkan secara optimal oleh masyarakat.

Pada tahun 2019, program CSR Petani Maju 4.0 dikuatkan di tiga titik pengembangan untuk mencari pola terbaik yang bisa diterapkan secara masif. Titik pengembangan tersebut tersebar di dua Kelurahan yakni Kelurahan Senipah dan Kelurahan Handil Baru Darat. Pembangunan kapasitas kelompok adalah langkah awal dalam menjalankan program. Pada tahun 2019, lima orang perwakilan disekolahkan di Bumi Langit Institute Yogyakarta untuk belajar tentang pertanian Permakultur. Lima orang ini menjadi pionir dalam pelaksanaan program untuk mewujudkan pertanian yang ramah lingkungan dan mengurangi tingkat pengangguran.

Ketika pandemi Covid 19 melanda pada tahun 2020, mitra yang terlibat dalam program Petani Maju 4.0 membuat sebuah produk orisinil bernama sistem pertanian Pertakultur. Gagasan konsep Pertakultur adalah upaya untuk mengadopsi sistem Permakultur dengan penyesuaian berbasis

lokalitas yang ada di Kalimantan. Prinsip dasar sistem Pertakultur adalah nilai-nilai Permakultur yang bertujuan untuk menjaga keberlanjutan lingkungan.

Pelaksana sistem pertanian Pertakultur ini adalah para pemuda. Pada tahun 2020, sejumlah 33 pemuda terlibat dalam tiga kelompok yang tersebar di tiga titik. Selain pemuda, terdapat dua Kelompok Wanita Tani dengan jumlah 86 perempuan yang berpartisipasi. Sistem bertani ramah lingkungan dan beroganisasi adalah hal yang baru bagi para penerima manfaat. Sistem pertanian Pertakultur ini adalah upaya PHM Lapangan BSP melakukan formulasi inovasi sosial. Salah satu bentuk inovasi sosial menurut Tepsie (2014) ialah kebaruan sistem yang diterapkan di tengah masyarakat untuk menciptakan perubahan sosial. Inovasi sosial perlu dilakukan oleh Perusahaan agar bisa membuat perubahan sistematik di tengah masyarakat.

Banyak program CSR yang terkesan masih bertentangan dengan sifat pemberdayaan masyarakat yakni top-down, sentralistik dan universal. Hal tersebut yang mendasari pentingnya inovasi sosial dilakukan dalam program CSR. PHM Lapangan BSP telah berupaya untuk mengkonstruksi program dengan kaidah pemberdayaan masyarakat yang bersifat bottom-up, desentralistik dan variasi lokal sebagaimana yang dijelaskan oleh Soetomo (2013). Maka dari itu, artikel ini akan mengulas dimensi inovasi sosial yang ada dalam sistem Pertakultur program CSR Petani Maju 4.0 PHM Lapangan BSP yang memberikan kekuatan dan kewenangan kepada masyarakat untuk menjadi subjek pembangunan. 
Learning Society: Jurnal CSR, Pendidikan dan Pemberdayaan Masyarakat

Jurnal Program Studi Pendidikan Masyarakat

Universitas Mulawarman

Vol. 2 No. 1, Juni 2021. Hal: 9-13

\section{Kerangka Konseptual}

Kerangka teori yang dikonstruksi sebagai pisau analisis dalam penelitian ini adalah inovasi sosial. Penulis merumuskan definisi konseptual dari inovasi sosial menjadi suatu kerangka berpikir. Kerangka berpikir ini berfungsi untuk menjelaskan dimensi inovasi sosial dalam sistem pertanian Pertakultur Program Petani Maju 4.0. Konsep utama yang digunakan adalah konsep inovasi sosial dari Tepsie. Tepsie (2014) mendefinisikan inovasi sosial sebagai pendekatan baru untuk pemetaan kebutuhan sosial. Pada pendekatan inovasi sosial, melibatkan para penerima manfaat untuk membangun kekuatan hubungan sosial. Kekuatan hubungan sosial ini berperan untuk mendapatkan akses kewenangan terhadap sumber daya (Tepsie, 2014:13).

Tepsie (2014) menjelaskan bahwa ada dua dimensi dalam inovasi sosial. Dimensi ini meliputi bentuk inovasi sosial dan karakter inovasi sosial. Dimensi bentuk inovasi sosial terdiri dari lima. Pertama, bentuk kebaruan dari program. Hal apa yang baru dan berbeda dengan tempat lain. Kebaruan yang dimaksud disini adalah tidak sepenuhnya baru, tetapi aktivitas program yang baru dilakukan oleh penerima manfaat. Bentuk yang kedua adalah memenuhi kebutuhan sosial yang dasar. Program disusun untuk menjawab kebutuhan dasar dengan mempertimbangkan kebudayaan lokal. Bentuk ketiga adalah program sudah terimplementasikan di tengah masyarakat. Program yang terimplementasikan menjadi indikator bahwa inovasi sosial bukan hanya sekedar konsep. Bentuk keempat program harus melibatkan penerima manfaat dengan meningkatkan kapasitas. Program harus melibatkan multistakeholder dalam proses pengasahan pengetahuan dan keterampilan. Bentuk kelima berupa transformasi hubungan sosial yang berkeadilan dalam proses distribusi kewenangan (Tepsie, 2014:13-14).

Kemudian dimensi kedua yaitu karakter inovasi sosial terdiri dari empat. Karakter pertama, inovasi sosial bersifat bottom-up bukan top-down. Karakter ini ada dalam proses penyusunan dan implementasi program. Penerima manfaat adalah subjek bukan objek dari pembangunan. Karakter inovasi sosial yang kedua berupa tingkat kepastian yang tinggi. Kepastian ini berupa berbagai keputusan yang akan mempengaruhi hasil. Tujuan yang dicapai harus konkret, tidak pada level abstrak. Karakter ketiga inovasi sosial terinternalisasi dalam kebiasaan dan struktur. Inovasi sosial hendaknya menjadi kebiasaan dalam struktur kelompok. Karakter keempat adalah meminimalisir konsekuensi yang kemungkinan timbul dari proses pelaksanaan inovasi sosial.

Untuk melihat pola dua dimensi inovasi sosial tersebut, penulis menggunakan konsep Individual Institutional Opportunity Nexus (IION). Menurut Kusworo (2015) IION adalah ruang interaksi tempat bertemunya agen dan struktur. Sementara menurut parker (2010) mengemukakan bahwa agen dan struktur memiliki hubungan yang bersifat dualitas. Kemudian Rohmawati (2015) menjelasakan dua pandangan ini bahwa agen dan struktur yang berinteraksi di ruang IION memiliki dua pola. Pola pertama adalah relasi antara agen dan struktur. Pola kedua interaksi antar agen dengan agen dan struktur dengan 
Learning Society: Jurnal CSR, Pendidikan dan Pemberdayaan Masyarakat

Jurnal Program Studi Pendidikan Masyarakat

Universitas Mulawarman

Vol. 2 No. 1, Juni 2021. Hal: 9-13

struktur. Kedua pola ini bisa terjadi dalam satu

waktu seperti gambar berikut.

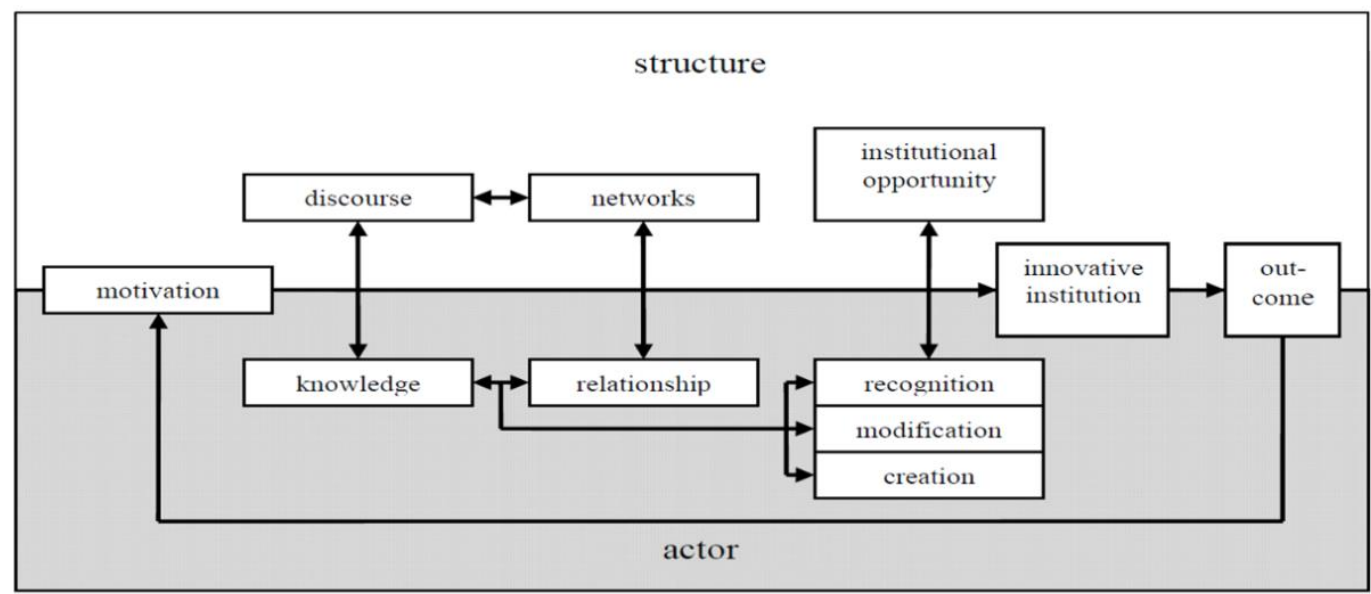

Gambar 1 Individual-Institutional Opportunity Nexus,

Sumber (Kusworo, 2015)

Pola interaksi antara agen dan struktur dipengaruhi oleh berbagai unsur dalam setiap level. Inovasi muncul dari motivasi untuk menyelesaikan masalah sosial dengan hal yang baru. Motivasi akan menghasilkan institusi inovatif dan outcome. Berkaitan dengan dimensi inovasi sosial pada sistem pertanian Pertakultur, ada tiga unsur di level agen/aktor maupun pada level struktur.

Pada unsur level aktor harus terdapat pengetahuan, hubungan antar aktor dan konteks sistem pertanian Pertakultur melakukan modifikasi sistem Permakultur. Tiga unsur ini saling berkaitan satu sama lain di level aktor. Sementara pada level struktur harus terpenuhi unsur diskursus, jaringan dan peluang pengembangan intitusi. Tiga unsur level struktur memiliki keterkaitan dalam lingkup struktur. Kemudian dalam waktu yang sama berkaitan antar unsur di level aktor dan level sistem. Konsep ini akan memberikan gambaran mengenai pola inovasi sosial yang terbentuk dalam sistem pertanian Pertakultur.

\section{Metode Penelitian}

Proses penelitian dan penyusunan artikel ini menggunakan metode penelitian kualitatif. Pendekatan kualitatif yang digunakan adalah analisis deskriptif. Sasaran pendekatan kualitatif adalah kehidupan sosial yang komprehensif. Subjek penelitian berupa fenomena sosial yang membentuk pola, prinsip kehidupan dan sistem sosial di tengah masyarakat (Rudianto, et al: 2012:97). Kualitatif deskriptif menekankan pada proses merangkai pola kehidupan masyarakat yang terbentuk menjadi sistem.

Creswell (2015) mengatakan bahwa ciri utama kualitatif deskriptif adalah mengumpulkan cerita dari individu mengenai pengalaman. Cerita dari individu tersebut merepresentasikan identitas dari individu di tengah sistem sosial. Cerita yang didapatkan disusun menjadi sebuah rangkaian kronologis untuk menjabarkan proses pelaksanaan sistem Pertakultur dalam program Petani Maju 4.0 yang membentuk dimensi inovasi sosial. 
Learning Society: Jurnal CSR, Pendidikan dan Pemberdayaan Masyarakat

Jurnal Program Studi Pendidikan Masyarakat

Universitas Mulawarman

Vol. 2 No. 1, Juni 2021. Hal: 9-13

Creswell (2015) menekankan pentingnya memperhatikan struktur kasus yang diteliti. Struktur kasus berupa identifikasi masalah dan menguatkan desain metode penelitian yang dilakukan.

Pendekatan kualitatif deskriptif digunakan untuk mendesain konstruksi sistem Pertakultur dalam program Petani Maju 4.0 sebagai sebuah inovasi sosial. Unit analisis dari penelitian ini adalah para penerima manfaat program Petani Maju 4.0 yang menjadi subjek penelitian. Penelitian ini berupaya untuk melihat solidaritas organik yang terbentuk di tengah penerima manfaat yang mampu mengkonstruksi program untuk memenuhi dimensi inovasi sosial. Hal ini disebabkan karena inovasi sosial muncul di tengah penerima manfaat dengan pendekatan bottom-up.

Pengumpulan data dilakukan dengan teknik observasi, wawancara dan focus grup discussion di tiga lokasi pelaksanaan Program Petani Maju 4.0. Pengumpulan data dilakukan dari bulan Januari sampai Februari 2021. Penentuan informan yang diwawancarai menggunakan teknik purposive sampling. Teknik purposive sampling menentukan informan berdasarkan tujuan penelitian dan memilih informan yang paling refresentatif (Creswell, 2015:207). Pada pengumpulan data ini, peneliti menentukan 11 informan dari penerima manfaat yang dianggap paling representatif.

Analisa data yang didapatkan menggunakan kaidah dalam penelitian kualitatif. Menurut Creawell (2015) ada beberapa tahap dalam analisa data kualitatif. Tahap pertama adalah mengorganisir data

yang didapatkan dari berbagai informan dalam suatu tabel. Tahap kedua membaca kembali dan membuat catatan penting mengenai informasi yang didapatkan. Tahap ketiga mendeskripsikan, mengklarifikasi dan menafsirkan data. Tahap keempat adalah menyajikan data dalam bentuk deskriptif maupun visual.

\section{Hasil dan Pembahasan}

Program pengembangan masyarakat Petani Maju 4.0 PHM Lapangan BSP telah dilaksanakan sejak tahun 2018. Program ini muncul untuk menjawab permasalahan sosial yang ada di wilayah pengembangan masyarakat PHM Lapangan BSP. Identifikasi permasalahan di wilayah pengembangan masyarakat dilakukan dengan social mapping dan focus grup discussion. Permasalahan yang muncul di PHM Lapangan BSP adalah isu pengangguran, minimnya regenerasi petani dan potensi kerusakan lingkungan karena pola pertanian yang kurang ramah lingkungan. Pada sisi lain, terdapat potensi pengembangan di bidang pertanian dengan ketersediaan lahan tidur yang belum dikelola optimal oleh masyarakat. Program Petani Maju 4.0 dengan inovasi sistem pertanian Pertakultur hadir untuk mengurangi permasalahan dengan berbasis pada potensi lokal yang dimiliki oleh masyarakat di bidang pertanian.

\section{Dimensi Bentuk Inovasi Sosial}

Tepsie (2014) mengklasifikasi empat bentuk inovasi sosial. Sebuah ide, kegiatan, maupun program harus memenuhi empat indikator ini agar dapat dikatakan sebagai sebuah inovasi sosial. Bentuk pertama adalah unsur kebaruan yang membedakannya dengan bentuk lainnya. Bentuk kedua harus 
Learning Society: Jurnal CSR, Pendidikan dan Pemberdayaan Masyarakat

Jurnal Program Studi Pendidikan Masyarakat

Universitas Mulawarman

Vol. 2 No. 1, Juni 2021. Hal: 9-13

memenuhi kebutuhan dasar masyarakat, baik

skala kecil maupun besar. Bentuk ketiga

sudah terimplementasikan sebagai bentuk

validitas dari sebuah inovasi. Kemudian bentuk

keempat berbasis pada peningkatan kapasitas masyarakat. Berkaitan dengan dimensi sistem pertanian Pertakultur dapat dilihat pada tabel berikut.

\section{Tabel 1 Dimensi Bentuk Inovasi Sosial Sistem Pertanian Pertakultur}

\begin{tabular}{|l|l|l|}
\hline No & Indikator & Dimensi Bentuk Inovasi Sosial \\
\hline 1 & Kebaruan & $\begin{array}{l}\text { Kebaruan pada program Petani Maju 4.0 terletak pada sistem } \\
\text { pertanian Pertakultur yang dijalankan. Pertakultur memiliki } \\
\text { kebaruan dari sisi nama, konsep dan operasional. }\end{array}$ \\
\hline 2 & $\begin{array}{l}\text { Memenuhi Kebutuhan Sosial } \\
\text { Dasar }\end{array}$ & $\begin{array}{l}\text { Memenuhi kebutuhan dasar petani berupa pupuk cair dan } \\
\text { pupuk organik yang diproduksi skala rumah tangga }\end{array}$ \\
\hline 3 & Terimplementasikan & Program sudah berjalan efektif sejak tahun 2019 \\
\hline 4 & Peningkatan Kapasitas & $\begin{array}{l}\text { Kapasitas masyarakat ditingkatkan dengan berbagai } \\
\text { pelatihan, pengalaman berorganisasi dan manajemen } \\
\text { kelompok }\end{array}$ \\
\hline
\end{tabular}

Pertama, bentuk kebaruan Pertakultur.

Kebaruan pada program Petani Maju 4.0 terletak pada sistem pertanian Pertakultur yang dijalankan. Pertakultur memiliki kebaruan dari sisi nama, konsep dan operasional. Nama Pertakultur merupakan istilah yang diciptakan oleh PHM Lapangan BSP. Nama Pertakultur memiliki filosofi brand pertanian yang dijalankan oleh Pertamina. Kata "Perta" ialah sinonim dari "Pertamina" yang berarti energi dan "Kultur" berarti pertanian sehingga Pertakultur memiliki makna "Pertanian Pertamina yang memberikan energi kepada para petani".

Kebaruan dari sisi konsep terletak pada ide untuk menghadirkan pertanian yang ramah lingkungan dengan berlaku adil untuk alam. Konsep Pertakultur mengadopsi konsep pertanian Permakultur sederhana. Permakultur sendiri merupakan konsep pertanian permanen yang mengedepankan perbaikan alam dalam proses pengelolaan pertanian. Kondisi tanah dan geografis Kalimantan yang berbeda dengan tanah Jawa membuat Permakultur harus disesuaikan dengan kearifan lokal sehingga muncul konsep Pertakultur yang mengadopsi enam nilai utama Permakultur.

Aspek kebaruan operasional metode pertanian Permakultur yang memanfaatkan potensi sumber daya sekitar dengan cara reuse to useful. Permakultur ini menggunakan pupuk organik yang diproduksi sendiri oleh kelompok petani dan memanfaatkan limbah sawit sebagai media tanam. Hal tersebut mampu memberikan dampak perbaikan lingkungan, mulai dari pengurangan penggunaan bahan kimia, penghematan penggunaan air serta mengurangi emisi sebesar 163,6 CH4 pada tahun 2020 dengan penggunaan limbah organik yang berasal dari alam.

Kedua, untuk memenuhi kebutuhan sosial dasar. Program Petani Maju 4.0 telah memenuhi kebutuhan dasar kelompok tani berupa pupuk, skema irigasi dan peluang 
Learning Society: Jurnal CSR, Pendidikan dan Pemberdayaan Masyarakat

Jurnal Program Studi Pendidikan Masyarakat

Universitas Mulawarman

Vol. 2 No. 1, Juni 2021. Hal: 9-13

perluasan pasar. Tiga aspek ini yang menjadi

identifikasi masalah dasar yang dihadapi oleh

para petani di wilayah pengembangan

masyarakat PHM Lapangan BSP. Data

permasalahan ini didapatkan dari social

mapping tahun 2018 dan pembaharuan social

mapping yang dilakukan pada tahun 2019 dan 2020.

Kebutuhan dasar pemenuhan pupuk dilakukan dengan pelatihan pembuatan kompos dan pupuk cair. Berawal dari lima petani yang dikirim untuk belajar konsep Permakultur di Bumi Langit Jogja, salah satu outputnya adalah pembuatan pupuk organik cair. Setelah kembali diadakan penyebaran pengetahuan melalui pelatihan-pelatihan dalam kurun waktu 2019 sampai 2020. Hasil yang didapatkan pada tahun 2020 tercipta inovasi dekomposer bernama "Biotasuke" yang bermakna kehidupan tanah subur kembali. Saat ini, petani yang berada dalam naungan PHM mampu mengurangi penggunaan pupuk kimia.

Sementara untuk menjawab kebutuhan irigasi, PHM dan para petani membangun embung irigasi di wilayah pertanian RT 10 Kelurahan Senipah. Pembangunan embung ini dilakukan untuk menjawab masalah kekeringan di musim kemarau dan kebanjiran lahan di musim penghujan. Untuk memperkaya nutrisi air, embung dimanfaatkan untuk pemeliharaan lele. Kemudian untuk menjawab kebutuhan di hilir pertanian berupa pemasaran, PHM dan kelompok pemuda tani mengembangkan aplikasi tanam digital. Aplikasi ini dikelola oleh para pemuda di Kampung Kamal Kelurahan Senipah. Proses digitalisasi ini bertujuan untuk meminimalisir pergerakan agar menekan

potensi penyebaran Covid 19. Pemasaran melalui aplikasi tanam digital meliputi wilayah Kecamatan Samboja, Kecamatan Muara Jawa, Kabupaten Kutai Kertanegara dan Kota Balikpapan.

Ketiga, bentuk terimplementasikan. Program Petani Maju 4.0 telah berjalan sejak tahun 2018. Proses dimulai dari identifikasi masalah serta pemetaan sosial yang menghasilkan visi dan tujuan program. Sistem Pertakultur sendiri baru terlaksana pada tahun 2019 dengan peletakan konsep-konsep dasar Permakultur.

Konsep dasar Pertakultur yang terimplementasikan meliputi enam aspek Permakultur. Aspek pertama, menyehatkan alam. Hasil dari upaya menyehatkan alam pada tahun 2020 ialah pengurangan emisi $\mathrm{CH} 4$ dari limbah perkebunan sebesar $139.6 \mathrm{~kg}$ $\mathrm{CH} 4 /$ thn dan pengurangan emisi dari produksi pupuk cair sebesar $24 \mathrm{~kg} \mathrm{CH} 4 /$ thn (ITK, 2020). Aspek kedua, seni menata lahan. PHM melalui sistem Pertakultur telah membuat skema penataan lahan seluas 5,12 Ha di Kelurahan Senipah dan Kelurahan Handil Baru Darat, Kecamatan Samboja. Aspek ketiga, daur ulang limbah. Pemanfaatan limbah perkebunan sawit $270 \mathrm{Kg} /$ bulan dan rumah tangga menjadi produk pertanian Pupuk Organik Cair 45 liter/bulan. ${ }^{3}$

Aspek keempat, perluasan manfaat. Capaian pada tahun 2020, 47 pekarangan warga di Kampung Kamal, Kelurahan Senipah. Selanjutnya terdapat embung yang dimanfaatkan untuk irigasi pertanian yang mampu menampung air dengan volume 1,050

\footnotetext{
${ }^{3}$ Laporan Implementasi Program Pengembangan Masyarakat PHM Tahun 2020
} 
Learning Society: Jurnal CSR, Pendidikan dan Pemberdayaan Masyarakat

Jurnal Program Studi Pendidikan Masyarakat

Universitas Mulawarman

Vol. 2 No. 1, Juni 2021. Hal: 9-13

$\mathrm{M}^{3} .{ }^{4}$ Aspek kelima, kebermanfaatan bersama.

kapasitas individu dan kelompok yang terlibat Sistem pertanian Pertakultur memberikan kebermanfaatan terhadap lingkungan dan peningkatan pendapatan petani. Peningkatan pendapatan diperoleh dari penghematan penggunaan pupuk kimia sebesar Rp 500.000,- sampai Rp 1.000.000,-. Aspek keenam, mandiri dan berkelanjutan. Bentuk nyata dari program yang sudah terimplementasi adalah terciptanya kemandirian yang berkelanjutan. Hal ini sudah mulai muncul dengan adanya kegiatan pertemuan rutin kelompok.

Keempat, bentuk peningkatan kapasitas. Program Petani Maju 4.0 dengan rangkaian sistem pertanian Pertakultur menjadikan masyarakat sebagai subjek dari pembangunan. Sehingga kapasitas individu dan kelompok ditingkatkan secara bertahap melalui berbagai metode. Metode pertama untuk peningkatan kapasitas yang dilakukan ialah studi banding. Studi banding dilakukan ke Bumi Langit Institute dan Mapantama pada tahun 2019. Studi banding bertujuan untuk memberikan gambaran mengenai pertanian ramah lingkungan.

Metode kedua dalam proses peningkatan kapasitas pengetahuan dan keterampilan ialah pelatihan. Kurun waktu 2018 sampai 2020 telah banyak pelatihan yang dilakukan untuk meningkatkan kapasitas masyarakat. Pelatihan dasar yang diberikan adalah pemahaman konsep Permakultur kepada perwakilan kelompok tani di Bumi Langit Institute Yogyakarta selama 3 hari dan 14 hari. Selain itu, ada berbagai macam pelatihan yang dilakukan untuk menguatkan

${ }^{4}$ Ibid 
Learning Society: Jurnal CSR, Pendidikan dan Pemberdayaan Masyarakat

Jurnal Program Studi Pendidikan Masyarakat

Universitas Mulawarman

Vol. 2 No. 1, Juni 2021. Hal: 9-13

Tabel 2 Dimensi Karakter Inovasi Sosial Sistem Pertanian Pertakultur

\begin{tabular}{|l|l|l|}
\hline No & Indikator & Dimensi Karakter Inovasi Sosial \\
\hline 1 & Bottom-Up & $\begin{array}{l}\text { Karakter bottom-up pada sistem pertanian } \\
\text { Pertakultur terletak pada proses pengambilan } \\
\text { keputusan yang senantiasa melibatkan kelompok } \\
\text { tani. }\end{array}$ \\
\hline 2 & Memiliki tingkat kepastian & $\begin{array}{l}\text { Program Petani Maju } 4.0 \text { melalui sistem pertanian } \\
\text { Pertakultur memiliki tingkat kepastian pelaksanaan } \\
\text { sesuai dengan konsep yang telah disepakati } \\
\text { bersama. PHM memberikan kepastian totalitas } \\
\text { dukungan moril dan materil. Kelompok tani perlahan } \\
\text { namun pasti mulai memperoleh kepastian yang lebih } \\
\text { baik dengan sistem pertanian Pertakultur. }\end{array}$ \\
\hline 3 & Terinternalisasi & $\begin{array}{l}\text { Enam nilai dasar sistem pertanian Pertakultur } \\
\text { terinternalisasi dalam sistem kerja cSR PHM } \\
\text { Lapangan BSP dan Kelompok Tani }\end{array}$ \\
\hline 4 & Meminimalisir Konsekuensi & $\begin{array}{l}\text { Sistem pertanian Pertakultur adalah bentuk nyata } \\
\text { upaya preventif untuk memperbaiki lingkungan } \\
\text { pertanian yang lebih ramah lingkungan dan } \\
\text { berkelanjutan. Hal ini meminimalisir permasalahan } \\
\text { potensial yang dihadapi petani berupa menurunnya } \\
\text { tingkat kesuburan tanah, kekurangan air dan nutrisi, } \\
\text { sampai pada konsekuensi pemasaran hasil } \\
\text { pertanian }\end{array}$ \\
\hline
\end{tabular}

sehingga muncul kemandirian dan partisipasi

Karakter pertama bottom-up anggota kelompok (Soetomo, 2013:71-78).

merupakan perspektif dalam proses pemberdayaan masyarakat. Karakter bottomup merupakan pergeseran dari karakter topdown. Pada karakter bottom-up, kelompok sasaran dilibatkan dan mampu mengidentifikasi permasalahan yang dihadapi. Hasil identifikasi masalah ini dapat ditindaklanjuti dengan dua pola. Pola pertama, diidentifikasi oleh kelompok dan diselesaikan langsung oleh kelompok sasaran. Pola kedua, diidentifikasi oleh kelompok dan diselesaikan bersama dengan stakeholder di luar kelompok

Konsep sistem pertanian Pertakultur muncul dari identifikasi masalah masyarakat di Kelurahan Senipah, Kelurahan Handil Baru dan Kelurahan Handil Baru Darat, Kecamatan Samboja. Petani memiliki berbagai permasalahan yang berkaitan dengan sistem pertanian yang dijalani. Permasalahan ini secara tidak langsung memberikan pengaruh terhadap minimnya minat generasi muda untuk bertani. Mekanisme bottom-up pola kedua berjalan dalam kasus ini. Pada tahun 2019, terjadi berbagai diskusi formal dan non-formal antara petani dan PHM Lapangan BSP. 
Learning Society: Jurnal CSR, Pendidikan dan Pemberdayaan Masyarakat

Jurnal Program Studi Pendidikan Masyarakat

Universitas Mulawarman

Vol. 2 No. 1, Juni 2021. Hal: 9-13

Diskusi tersebut menghasilkan kesepakatan bersama untuk menjalankan pertanian ramah lingkungan dengan bingkai konsep Pertakultur.

Karakter kedua berupa tingkat kepastian tinggi dalam sistem pertanian Pertakultur. Menurut Mulgan (2006) dalam Farransahat, dkk (2020), inovasi sosial merupakan hal baru sehingga rentan akan resiko ketidakpastian. Faktor yang mempengaruhi ketidakpastian ini adalah tingkat kegunaan yang rendah dan minimnya dukungan stakeholder. Maka dari itu, Tepsie (2014) menekankan pentingnya tingkat kepastian dalam karakter inovasi sosial. Tingkat kepastian tinggi berupa komitmen antar stakeholder untuk mendukung setiap kesepakatan hal baru yang menjadi inovasi sosial.

Konsep sistem pertanian Pertakultur menawarkan tingkat kepastian tinggi untuk keberlanjutan lingkungan dan peningkatan ekonomi. Kepastian ini ditunjukkan oleh komitmen berbagai stakeholder terkait. Selain PHM Lapangan BSP dan Kelompok Tani, sistem pertanian Pertakultur yang ramah lingkungan mendapat dukungan dari pemerintah setempat, kajian beberapa universitas dan tentunya Dinas Pertanian Kabupaten Kutai Kertanegara. Komitmen dukungan ini memberikan kepastian yang tinggi kepada kelompok tani untuk menjalankan pola pertanian yang ramah lingkungan.

Karakter ketiga inovasi sosial terinternalisasi dalam kebiasaan dan struktur. Menurut Santana (2014), inovasi hadir sebagai manifestasi hasil berpikir manusia dalam menyelesaikan permasalahan sosial. Lebih

lanjut, Santana (2014) menjelaskan bahwa hasil pikiran memiliki korelasi yang kuat untuk membentuk kebiasaan dan struktur masyarakat. Hal ini sejalan dengan penjelasan Komisi Eropa (1995) dalam Rahmawati (2020) yang menyatakan inovasi sosial berfokus pada upaya untuk mengubah struktur masyarakat. Perubahan sosial ini bertujuan untuk menjawab permasalahan sosial yang dihadapi dalam kelompok masyarakat.

Pertakultur mendorong kelompok tani untuk menginternalisasi enam nilai yang diimplementasikan sebagai prinsip. Enam nilai ini telah diulas dalam bentuk implementasi inovasi Pertakultur. Enam nilai pertanian ramah lingkungan yang terimplementasi menjadi kebiasaan baru bagi kelompok tani. Nilai yang terimplementasi menjadi sebuah kebiasaan baru untuk menjalankan pertanian yang ramah lingkungan. Sebagai contoh, aktifitas pertanian di Kelompok Bumi Seraiwangi Kelurahan Senipah yang mampu memproduksi pupuk dan dekomposer sendiri sehingga proses hulu pertanian terjamin karakter ramah lingkungannya.

Kemudian karakter keempat adalah meminimalisir konsekuensi. Sejalan dengan penjelasan Farransahat, dkk (2020) yang menyatakan inovasi sosial memiliki kerentanan untuk gagal karena merupakan hal baru. Tentunya sistem pertanian Pertakultur memiliki konsekuensi, kerentanan dan tantangan. Konsekuensi yang harus dihadapi petani adalah mencoba sistem baru yang ramah lingkungan. Petani berusaha untuk meminimalisir pola pertanian yang tergantung dengan obat-obat kimia. Pola pertanian tersebut cepat mendapatkan hasil tetapi 
Learning Society: Jurnal CSR, Pendidikan dan Pemberdayaan Masyarakat Jurnal Program Studi Pendidikan Masyarakat

Universitas Mulawarman

Vol. 2 No. 1, Juni 2021. Hal: 9-13

memberikan kontribusi terhadap kerusakan

Kusworo (2015) menjelaskan tanah.

Sistem pertanian Pertakultur hadir untuk meminimalisir konsekuensi tersebut. Konsekuensi kerusakan lingkungan dilakukan dengan penggunaan pupuk cair dan dekomposer Biotasuke. Petani harus berdikari dengan meminimalisir ketergantungan pupuk kimia. Sementara konsekuensi penyerapan hasil pertanian dilakukan dengan pola Creating Share Value (CSV) antara petani dan PHM Lapangan BSP. Hasil tani sebagian diserap oleh catering PHM Lapangan BSP agar karyawan mendapatkan asupan sayur dan buah yang sehat dan segar. Selain itu, upaya perluasan pasar dilakukan dengan digitalisasi pemasaran melalui aplikasi 'Tanam Digital'. Aplikasi ini dikelola oleh Kelompok Remaja Tani Kampung Kamal Kelurahan Senipah.

\section{Dimensi Individual Institutional Opportunity Nexus (IION) Sistem Pertakultur} Individual Institutional Opportunity Nexus (IION) adalah ruang relasi hubungan antara agen dan struktur. Menurut Parker (2010) agen dan struktur memiliki hubungan yang bersifat dualitas. Artinya, agen dan struktur dapat saling mempengaruhi satu sama lain dengan karakternya. Konsep IION menjelaskan hubungan agen dan struktur yang bersifat dualitas pada dimensi ruang interaksi, baik interaksinya terpisah maupun tak terpisah.

Pada konteks dimensi sosial dalam sistem pertanian Pertakultur, Penulis menggunakan dimensi konsep IION untuk menguatkan dimensi bentuk dan karakter inovasi sosial Pertakultur. Bentuk dan karakter inovasi sosial yang dikemukakan oleh Tepsie (2014) tidak lepas dari hubungan agenda dan struktur. Dimensi bentuk dan karakter inovasi sosial sistem pertanian Pertakultur menghasilkan hubungan agen dan struktur seperti pada gambar di bawah ini.

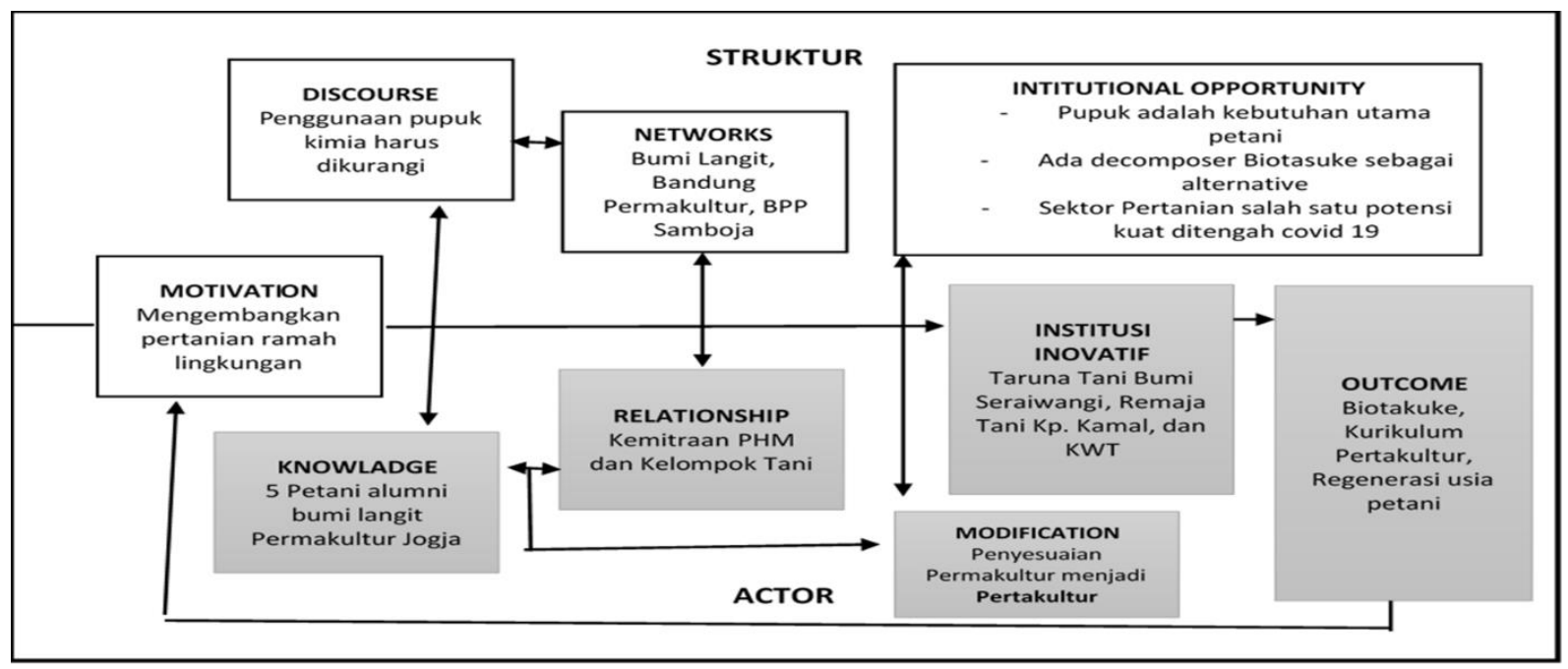

Gambar 2 IION Dimensi Inovasi Sosial Sistem Pertanian Pertakultur 
Learning Society: Jurnal CSR, Pendidikan dan Pemberdayaan Masyarakat

Jurnal Program Studi Pendidikan Masyarakat

Universitas Mulawarman

Vol. 2 No. 1, Juni 2021. Hal: 9-13

Gambar di atas menunjukkan bahwa

Pada level sistem terdapat diskursus, dimensi bentuk dan karakter inovasi sosial sistem Pertakultur telah membentuk ruang interaksi baru antara agen dan struktur. Relasi antara agen dan struktur yang terbentuk disini menunjukkan kekuatan sistem pertanian Pertakultur. Kekuatan tersebut melekat pada level individu dan struktur di wilayah pengembangan masyarakat PHM Lapangan BSP.

Masyarakat termotivasi untuk mengembangkan pertanian ramah lingkungan dan menjawab masalah sosial di sekitar wilayah pengembangan masyarakat PHM Lapangan BSP. Pada triwulan pertama tahun 2021, telah menghasilkan berbagai institusi inovatif. Institusi inovatif ini lahir sepanjang tahun 2019 sampai 2021. Institusi inovatif berupa kelompok tani yang tersebar di tiga Kelurahan di Kecamatan Samboja. Motivasi dan institusi inovatif telah menghasilkan outcome regenerasi petani dengan keterlibatan 33 pemuda tani, kurikulum Pertakultur dan produk unggulan dekomposer Biotasuke.

Outcome dapat tercapai karena di level agen atau aktor terdapat pengetahuan yang dimiliki oleh lima petani yang belajar di Bumi Langit Institute. Selanjutnya, terdapat hubungan kemitraan yang baik antara PHM Lapangan BSP dengan Kelompok Tani. Pengetahuan dan hubungan ini menghasilkan modifikasi sistem Permakultur menjadi sistem Pertakultur. Sebagaimana dijelaskan pada pembahasan sebelumnya, konsep Pertakultur muncul dari berbagai diskusi formal dan nonformal antara Kelompok Tani dengan PHM Lapangan BSP. 
Learning Society: Jurnal CSR, Pendidikan dan Pemberdayaan Masyarakat

Jurnal Program Studi Pendidikan Masyarakat

Universitas Mulawarman

Vol. 2 No. 1, Juni 2021. Hal: 9-13

Dimensi inovasi sosial yang melekat pada

sistem Pertanian Pertakultur berupa bentuk dan karakter yang terimplementasikan serta terinternalisasi dalam struktur. Kebaruan sistem yang ditawarkan dalam Pertakultur mampu memberikan tingkat kepastian tinggi dan meminimalisir resiko sistem pertanian. Hal ini didukung dengan kapasitas kelompok tani yang dikembangkan dari sisi pengetahuan dan keterampilan. Pengasahan pengetahuan dan keterampilan mampu memberikan kekuatan dan kewenangan kepada kelompok tani. Kekuatan dan kewenangan merupakan unsur utama dalam pemberdayaan masyarakat.

Pola inovasi sosial yang terbentuk dalam sistem pertanian Pertakultur tergambar dalam Individual Institutional Opportunity Nexus (IION). Terdapat relasi antara agen dan struktur sosial dalam sistem pertanian Pertakultur. Relasi yang terbangun menjadi sebuah pola yang kuat di level agen dan struktur. Pola telah dikembangkan dari unsur kebaruan inovasi sistem Pertakultur. Pola ini terimplementasikan dengan tujuan untuk menghadirkan pertanian yang ramah lingkungan serta memberikan kontribusi terhadap peningkatan ekonomi petani sehingga pemuda bisa lebih tertarik kembali ke dunia pertanian dan menjadi solusi untuk permasalahan pengangguran terbuka di wilayah pengembangan PHM Lapangan BSP.

\section{Daftar Pustaka}

Cajaiba-Santana, G. 2014. Social innovation: Moving the field forward: conceptual framework. Technological Forecasting and Social Change, 82, 42-51. 7 https://doi.org/10.1016/j.techfore.2013. 05.008 .

Creswell, Jhon W.2015.Penelitian Kualitatif dan Desain Riset.Yogyakarta:Pustaka Pelajar

Farransahat, M., Damayanti, A., Suyatna, H., Indroyono, P., \& Firdaus, R. (2020). Pengembangan Inovasi Sosial Digital: Studi Kasus Pasarsambilegi.id. Jurnal Social Development Studies UGM, 1 (2): 14-26

Kalimantan, I. T. (2020). Laporan Kajian Lingkungan Program CSR PT. Pertamina Hulu Mahakam. Balikpapan: Institut Teknologi Kalimantan.

Kusworo, H. A. (2015). Framing Poverty : An institutional entrepreneurship approach to poverty alleviation through tourism. Groningen: University of Groningen.

Mulgan, G. (2006). The process of social innovation. Innovations: Technology, Governance, Globalization, 1(2), 145162.

Mulyani, A., Kuncoro, D., Nursyamsi, D., \& Agus, F. (2016). Analisis Konversi Lahan Sawah: Penggunaan Data Spasial Resolusi Tinggi Memperlihatkan Laju Konversi yang Mengkhawatirkan. Jurnal Tanah dan Iklim 40 (2): 14-26.

Parker, J. (2000). Structuration theory. Buckingham: Open University Press.

Prayogo, K., Nurfadillah , S., Saragih, M., \& Riezky, A. M. (2019). Menakar Perubahan Sosio-Kultural Masyarakat Tani Akibat Miskonsepsi Modernisasi 
Learning Society: Jurnal CSR, Pendidikan dan Pemberdayaan Masyarakat Jurnal Program Studi Pendidikan Masyarakat

Universitas Mulawarman

Vol. 2 No. 1, Juni 2021. Hal: 9-13

Pembangunan Pertanian. Jurnal

Sosial, Ekonomi, dan Agribisnis, 13

(1): 96-114.

Rahmawati. (2020). Komunitas Baca Rumah

Luwu Sebagai Inovasi Sosial Untuk

Meningkatkan Minat Baca Di

Kabupaten Luwu. Jurnal Pendidikan

Luar Sekolah UNY, 4 (2): 158-168.

Rohmawati, D. (2015). Kewiralembagaan dalam Pengelolaan Sampah Berbasis Masyarakat di Bank Sampah Gemah Ripah, Badegan, Bantul. Jurnal Studi Pemuda. 4 (2): 296-314.

Rudito, Bambang dan Melia Famiola. 2012.

Social Mapping : Metode Pemetaan

Sosial. Bandung : Rekayasa Sains

Soetomo. 2013. Pemberdayaan Masyarakat; Akankan Muncul Anti Tesisnya.Yogyakarta : Pustaka Pelajar

Tepsie. (2014). Social Innovation Theory and Research A Guide for Researchers. Uni Eropa: Seven Framework Programe. 